\title{
Схематизація просторових відношень в англійській, сербській, українській мовах: специфіка прийменника оver
}

К л ю ч о в і с л о в а: прийменник; просторова сцена; траєктор; орієнтир; схема; концептуалізація

K e y w ord s: preposition; spatial scene; trajector; landmark; schema; conceptualization

Вивчення сприйняття простору, категоризації та вербалізації просторових відношень - одна з найактуальніших ділянок дослідження в сучасній науці. S. Levinson (2003: 131) стверджує, що просторові уявлення є основою для великої частини наших непросторових уявлень, i це зумовлено тим, що п р остір є центральним когнітивним доменом для будь-якого рухомого створіння, а людське мислення $є$ глибоко просторовим, оскільки більшість інформації про світ ми отримуємо перцептивно. Одним із основних мовних засобів вираження просторових сцен $є$ прийменник. У цій статті зосередимо увагу на відмінностях у концептуалізації деяких просторових відношень в англійській, сербській та українській мовах. 
Вже більше 30-ти років провадять дослідження семантики англійських прийменників із позицій когнітивної лінгвістики, які й становлять теоретичне та методологічне підгрунтя цього дослідження (Brugman 1988; Herskovits 1986; Lakoff 1990; Langacker 2000; Talmy 2000, Tyler, Evans 2003). Дослідження значень прийменниково-відмінкових конструкцій у сербській мові доволі поширені серед лінгвістів, значну частку яких становлять праці М. Ивић $(1958,2010)$. Когнітивні студії семантики прийменників сербської мови здійснює D. Klikovac (2006), P. Piper (2001). Љ. Поповић (2008) системно вивчає концептуалізацію простору у мовній картині світу сербів на матеріалі дієслівних префіксів та проводить зіставлення з українською мовою. K. Rasulić (2004) досліджує особливості концептуалізації простору англійською та сербською мовами.

Загалом когнітивні дослідження репрезентації просторових відношень у слов'янських мовах $\epsilon$ доволі актуальними. Системне дослідження концептуалізації простору та її представлення прийменниковими конструкціями у слов'янських мовах здійснила Lj. Šarić (2008). L. Janda (1986) проаналізувала семантичну структуру російських дієслівних префіксів за-, пере-, до-, om-, R. Przybylska (2006) - образні схеми польських дієслівних префіксів do-, od-, prze-, roz-, u-, а також семантичну мережу низки польських прийменників (Przybylska 2002). M. Brenda (2014) вивчає кореляцію значень over 3 прийменниками польської мови.

Прийменники ж української мови досліджувались у структурному та функційному аспектах (напр., Вихованець 1980, 2002; Загнітко 2002, 2008, 2014 та ін.). Ведуться дослідження динаміки прийменникового корпусу, визначення шляхів поповнення прийменникової системи, виявлення особливостей репрезентації власне прийменників і невласне прийменників, визначення їхніх структурних типів тощо. Зокрема, запропоновано концепцію електронного опрацювання українських прийменників та окреслено відносно граничний інвентар українських прийменників iз урахуванням формально-граматичного, семантико-синтаксичного та функційно-комунікативного підходів (Загнітко 2004, Вихованець 2009) у межах міжнародного наукового проекту „Слов’янські прийменники у синхронії і діахронії: морфологія і синтаксис“, до якого залучено фахівців з України, Білорусі, Росії, Болгарії, 
Сербії та Польщі (Всеволодова 2004). Пропри те, що інтерес до семантичного обсягу прийменників і прийменникових конструкцій дедалі зростає, семантичний аспект прийменників української мови й досі відзначено недостатньою вивченістю у зв'язку з мисленнєвими структурами, що ускладнює визначення відмінностей і проведення паралелей між основними когнітивними механізмами у різних мовах.

Виходячи зі схематизації простору, яку репрезентує слово over, і зіставляючи зі схематизацією подібних просторових сцен в українській та сербській мовах, можемо прослідкувати відмінності в концептуалізації просторових відношень, що є метою дослідження. Об’єктом вивчення стали семантичні відношення у граматичних конструкціях із прийменником over англійської мови, частково корелятивними прийменниками над, через української мови і прийменниками preko і nad сербської мови. Матеріал дослідження - 1000 контекстів iз over, 641 контекст із через, 694 - з українським над і його фонетичними варіантами надi, надо, 600 контекстів з preko і 400 - 3 сербським nad. Джерельною базою для англійської мови слугував Британський національний корпус (British National Corpus, BYU-BNC ${ }^{1}$ ). Фактологічний матеріал сербської мови було вилучено 3 Kopnyсу сучасної сербської мови (Korpus savremenog srpskog jezika, 201322). Оскільки Український національний лінгвістичний корпус УМІФ поки що недоступний для широкого загалу, можливі лише дослідження на матеріалах Корпусу текстів української мови (КТУМ ${ }^{4}$. Але матеріалом для визначення категорій значень, які концептуалізують первинні прийменники на сучасному етапі розвитку мов, мають бути тексти останніх 30-ти років. Такі тексти в КТУМ представлено в незначній кількості. Крім того, в КТУМ обмежено доступ до статистичних даних. Тому для дослідження було відібрано 28 текстів української мови,

1 BYU-BNC: British National Corpus - Режим доступу: http://corpus.byu.edu/ bnc/x.asp? $\mathrm{w}=1024 \& \mathrm{~h}=600$

${ }^{2}$ Korpus savremenog srpskog jezika, 2013 - Режим доступу: http://www.korpus. matf.bg.ac.rs/korpus/korpus2013.php

3 Український національний лінгвістичний корпус, створений Українським мовно-інформаційним фондом НАН України - Режим доступу: http://corp.ulif.org. ua/virt_unlc/

4 Корпус текстів української мови - проект Лінгвістичного порталу - Режим доступу: http://www.mova.info/corpus.aspx?11=209 
3 яких методикою суцільної вибірки вилучено контексти з обраними прийменниками.

Для визначення базового концептуального змісту кожного 3 прийменників вибрано контексти, у яких прийменники репрезентують просторові відношення. Відношення учасників просторової сцени асиметричні: один із учасників перебуває на першому плані, виконує роль фігури (Figure), а другий слугує точкою відліку для визначення розташування фігури, виконує функцію тла (Ground) (Talmy 2000: 184). R. Langacker (2000) використовує терміни траєктор (trajector, TR) та opiєнтир (landmark, LM) відповідно, якими і я буду послуговуватись.

Як пояснює L. Talmy (2000: 184), фігура (траєктор) найчастіше менша, мобільніша, представлена геометрично простіше (часто як точка), 3'являється пізніше у просторовій сцені й у свідомості; тло (орієнтир) зазвичай більше за розміром, більшою мірою фіксоване, геометрично складніше представлене, з'являється раніше у сцені й у пам'яті. У вербалізованій просторовій сцені прийменник вказує на місце розташування траєктора відносно орієнтира. Отже, взаємодію траєктора й орієнтира можна зобразити схематично, і саме ця схема експлікує концептуальний зміст, закладений у прийменнику. Схема містить конвенційний образ, який представлає прототипне значення прийменника. R. Langacker (2000) спирається на дослідження E. Rosch, яка встановила, що існують конвенційні образи прототипних членів категорії, ці образи у людей однієї культури дуже подібні. С також і конвенційні образи типових дій, пов'язаних із розташуванням і переміщенням предметів.

Безумовно, конкретні відношення профілює не лише прийменник, а вся прийменникова конструкція; значення руху, траєкторії профілює ситуативний контекст, переважно дієслово, але в деяких випадках і загальна прагматика та уявлення людини про світ. A. Tyler i V. Evans (2004: 16-19) розглядають прийменники через призму такої моделі світу, яку називають принциповою полісемією (principled polysemy), тобто значення, які профілюють прийменники в різних прийменникових конструкціях, утворюють семантичну мережу (semantic network); центральні значення (протосцена, proto-scene), які пов'язано з прийменниками, вирізняються за двома критеріями: 1) концептуальний зміст асоціюється лише з одним значенням; 2) зміст не залежить від контексту. 
Периферійні значення прийменників розвиваються завдяки широким дистрибутивним можливостям: різні типи траєктора й орієнтира забезпечують специфікацію сцени. Прийменникова конструкція в цілому ілюструє розвиток значення, яке пов'язано з прийменником, грунтуючись на протосцені або похідній схемі цього прийменника. Під час аналізу мовленнєвого матеріалу можемо визначити та проілюструвати мисленнєві механізми, які утворюють категорії траєктора й орієнтира, зумовлюючи розвиток значення прийменника. R. Przybylska (2002: 62-63) відзначила, що у наданні об'єкту певної просторової структури відіграє активну роль суб'єкт, який пізнає, т. зв. концептуалізатор; тобто мовець, який спостерігає певну сцену (етап переживання дійсності смислами), наштовхується на те, що бачить закладену в мові поняттєву мережу (етап концептуалізації), і наприкінці виражає всі переживання в мові (етап кодування понять через замикання їх у певних символічних осередках мови).

Протосцена, яка асоціюєтьсяз оver, містить просторовуконфігурацію, де TR розташовано вище LM-a. A. Tyler i V. Evans (2003: 65) апелюють до Оксфордського словника англійськоїмови (The Oxford English Dictionary): вихідне значення, пов'язане з формою over, виражає відношення ВИЩЕ TR-a i є співвідносним з above, як у (1). Різниця між over i above полягає в тому, що over позначає просторові відношення, у яких TR розташовано вище, ніж LM, але значною мірою в потенційному контакті з LM-ом, a above описує просторові відношення, в яких TR дуже близький до LM-a, (2). Функціональний елемент, який асоціюється 3 протосценою over: TR i LM перебувають у сфері взаємодії, впливу один на одного, як у реченні (3), - не характерний для above (Tyler, Evans 2003: 77).

(1) The picture is over the mantel.

(2) There are a few stray marks just above the line (Tyler, Evans 2003: 77).

(3) The aeroplane flew over Manhattan.

В українській і сербській мовах для прийменника над (+Ins. $\left.{ }^{5}\right)$ протосценою є відношення: ТРАЄКТОР ВИЩЕ ОРІСНИИА (СУМ 1974: 59;

5 У статті використовуємо латинські назви відмінків для уніфікації морфологічної термінології української та сербської мов. 
PCJ 2011: 744), між TR-ом і LM-ом контакт відсутній, але потенційно можливий (4), (5) і (6), (7), як і в (1) і (3). В українській і сербській мовах можливе вживання прийменників над / nad зі знахідним відмінком на позначення місця, куди спрямована дія, що відбувається 3 TR-oм. На сучасному етапі розвитку української мови конструкції над+Acc. не дуже частотні. У сербській мові конструкції nad + Acc. доволі частотні. Це пов'язано із поширенням у сербській мові прийменника iznad (+Gen.), який теж відображає відношення локалізації ТРАЄКТОР ВИЩЕ ОРІСНТИРА (РСЈ 2011: 445), та появою опозиції на основі статичностіњдинамічності просторової сцени. Так, nad + Асс. найчастіше профілює динамічну (лативну) сцену.

(4) Розплавився навіть давній латунний гуиульський мосяжний хрест, прибитий над входом.

(5) А це означало б, щчо він неминуче пролетить і над Львовом.

(6) ...posetioci mogu da operu ruke (ima i tople $i$ hladne vode) nad blještavo belim lavaboima.

(7) Sevanje munje koja je parala nebo nad Adom Ciganlijom oko 15 časova i pljusak koji je usledio nisu pokolebali ribolovce.

G. Lakoff (1990: 542) у своєму дослідженні визначає, що центральне значення over об'єднує елементи значень above 'зверху, над' і across 'через', стверджуючи, що over профілює динамічність, траєкторію руху TR-a. A. Tyler i V. Evans заперечують таку думку і послідовно доводять, що рух профілює в реченні дієслово, а траєкторію профілює властивість TR-a рухатися певним чином. У такому випадку, як (3), задіяна така ж схема, що й у (1). Прийменник over в обох випадках профілює лише ключову просторову конфігурацію TR-a як фігури відносно LM-a як фону: TR розташовано вище, ніж LM, у сфері взаємодії, і між елементами сцени можливий контакт (картина може впасти на камін, літак може приземлитися або впасти на територію Мангеттена).

Але в будь-якому разі, принаймні імпліцитно, просторова сцена, яку репрезентує over, має більше ніж одну точку локалізації (або лише можливості локалізації) TR-a в той чи інший момент, але тільки одна 3 них є опорною для сцени, вона і визначає схему відношень. Прийменник над української і сербської мови у протосцені містить лише 
одну точку локалізації TR-a (4), (5), (6), (7), на відміну від протосцени прийменників через (+Acc.) і preko (+Gen.), яка передбачає обов'язкове перебування TR-a більше ніж в одній точці сцени, акцентуючи на крайніх протилежних точках LM-a, (8), (9). У прототипній ситуації LM більший, ніж TR; згідно з СУМ (1980: 304) та PCJ (2011: 930-931) TR входить у межі LM-а з одного боку і виходить 3 нього з іншого боку, на що TR-y потрібен деякий час (10), (11), (12), (13). LM концептуалізується як перешкода на шляху TR-a. Саме така специфікація LM-a стає підгрунтям для розвитку похідних значень прийменника через.

(8) Дорога туди пролягала через пустир та неродючі пригірські городи.

(9) Pozivajući se na to da je za skuplji i komplikovaniji most preko Ade Ciganlije unapred dato svega 10 odsto novca...

(10) Іван не озираючись пішов через увесь передпокій...

(11) Ми пролазили через дріт і збирали гриби.

(12) Enoh se okrenu od mrtvog tela i drvenim koracima pređe preko sobe, pristupivši aparatu za odašiljanje poruka.

(13) Ovim brodom je trebalo da se kokain preveze do Evrope, preko Atlantskog okeana.

Від протосцени утворюються похідні значення на основі образної схеми і додаткових властивостей сцени. Іншими словами, поточний комплекс концептуалізації походить від протосцени, і зв'язок похідного значення з протосценою є основним. Однак, у багатьох випадках різні значення не прямо виводяться із протосцени в контексті речення, у якому вжито прийменник. Похідні значення утворюють розгалужену систему. Деякі значення можуть утворювати кластери, грунтуючись на подібності ситуації.

Кластер 'АВС-траєкторія'

A. Tyler i V. Evans (2003: 80) пропонують розгалужену схему для ілюстрації відношень, які в різних випадках репрезентує слово over. Найбільший кластер похідних значень має умовну назву 'АВСтраєкторія'. Усі значення, які утворюють кластер 'АВС-траєкторія', виникають унаслідок переосмислення схеми, де точки А і C лише 
імпліцитно представлено у реченнях (14) і (15). Ситуацію характеризують такі елементи: дієслово to јuтр визначає точку А як відправну точку; John (TR) не здатен зависнути в повітрі та має повернутися на землю - у точку $\mathrm{C}$; the fence (LM) побудовано як перешкоду для прямого руху TR-a; over позначає ключову позицію TR-a у цій ситуації - над LM-ом, вище, ніж LM.

(14) John jumped over the fence and went on.

(15) John climbed over the fence and went on.

Можлива наявність контакту між LM-ом і TR-ом, проте цей елемент сцени не є релевантним для значення прийменника over. Як зазначає G. Lakoff (1990: 542-543), контакт неможливо позначити на схемі, образна схема нейтральна в цьому відношенні. Тому вважаємо за доцільне наголосити, що у випадках (14) і (15) задіяно ту саму концептуальну схему.

Подібно до схеми 'АВС-траєкторія' прийменника over, побудовано протосцену через i preko. Точки А i C умовно представлено у схемі, відмінність полягає у тому, що точка В не є ключовою позицією у взаємодії із LM-ом. Безпосередній контакт не має значення, він може бути, як у (10) чи (12), або ні, (16), (17). Спільним є те, що LM концептуалізується як перешкода, яку можна подолати.

(16) У Святвечір не вільно подавати одне одному руку через поріг, розсипати сіль і бити дзеркала.

(17) Kada sam kročio preko praga, spazio sam priliku mladog čoveka otprilike moje visine, obučenog u beli jutarnji kaput od kašmira sašiven po najnovijoj modi...

Значення ' 3 -іншої-сторони-від’

Значення '3-іншої-сторони-від’ є варіацією схеми 'АВС-траєкторія'. Тут over використано для позначення ключової просторової конфігурації, в якій рух TR-a вже завершено, i TR розташовано з іншої сторони від LM-a, порівняно з відправною точкою траєкторії (Tyler, Evans 2003: 81). Te, що over не профілює траєкторію, підтверджує вживання over у сполученні не лише з динамічними дієсловами (18), а й із дієсловами, які 
вказують на локалізацію TR-a (19). Наявність чи відсутність траєкторії визначається контекстом, але не є принциповою для виникнення іншого значення over.

(18) Sam drove over the bridge (Lakoff 1990: 544).

(19) Arlington is over the Potomac River from Georgetown (Tyler, Evans 2003: 81).

Сдиною відмінністю цих ситуацій є те, що у (18) схематично зображено траєкторію TR-a, а у (19) - траєкторію погляду імпліцитного спостерігача, який розташовано на тому березі ріки Потомак, де лежить Джорджтаун, i, відповідно, це місце є вихідним пунктом траєкторії погляду; місце, на якому розташовано Арлінгтон, є цільовим пунктом погляду, а Потомак - орієнтиром, специфікованим як перешкода.

Ситуацію (18) українською мовою було би відображено як (20), а (19) дослівно можна перекласти як (21) із дещо відмінною від протосцени через схемою, в якій акцентовано точку С як стале розташування TR-a й умовну мету суб'єкта, але в українському мовному середовищі для такої ситуації частотніше вживання прийменника за, як у (21). В українській і сербській мовах прийменники через і preko репрезентують протосцену в (22), (23), тут задіяно структурну метафору ПОГЛЯД - ЦЕ ШЛЯХ, про яку прийменники й сигналізують. Значення '3-іншоїсторони-від’ прийменників через і preko забезпечує зміна у просторовій сцені: точка С є сталою позицією TR-a i ключовою у сцені, точка А представлена як розташування імпліцитного суб’єкта-спостерігача (21), (25).

(20) Семен переїхав через міст.

(21) Арлінгтон лежить через річку Потомак від Джорджтауна.

(22) Не знаю вже як, але й земля Телішова, - що ото яр за річкою за Козинкою, - і та теж відійшла до Куракіних.

(23) Стрий востаннє кинув поглядом через Дністер на похилену хатку і швидким кроками попрямував у темряву.

(24) Nateže luk, namesti strelu i okrete se, oštro gledajući nazad preko reke u tminu. 
(25) Ja sam za njegov put doznao od Liputina; uz razgovor doznao sam od njega i to da su Lebjatkini, brat i sestra, negde preko reke u Goršečnom podgrađu.

Прийменник за, як і over у (18) і (26), у просторовій сцені, (27), також імплікує спостерігача, який розташовано „поза сценою“ (“off-stage”), вихідним пунктом погляду є місце з одного боку LM-a, а цільовий збігається з локусом TR-a, тобто перебуває на протилежному боці від LM-a.

(26) The ball landed over the wall.

(27) М'яч приземлився (впав) за стіною.

Переосмислення over, яке відбувається у значенні '3-іншої-сторонивід’, містить дві зміни, порівняно із протосценою, - привілейованість точки C та інтерпретація ії як точки, поруч із якою локалізується TR, i зміна точки зору - відбувається зміщення позиції імпліцитного спостерігача у безпосередню близькість до точки A. A. Tyler i V. Evans (2003: 82) припускають, що це значення утворилося шляхом використання over у контексті, у якому значення ‘3-іншої-сторони-від’ було імпліцитним, і стало конвенційно асоційованим з over як відмінне значення, - такий процес дослідники називають прагматичним підкріпленням (pragmatic strengthening).

Схема надлишку

Значення 'Над-і-За' (The Above-and-beyond Sens) - у цьому значенні over вживається як передбачено протосценою, але з додатковим елементом: LM репрезентує передбачувану мету або ціль, а TR рухається далі передбачуваної або бажаної точки (Tyler, Evans 2003: 83).

(28) The arrow flew over the target and landed in the woods.

Випадок (28) відрізняється від (14) тим, що TR рухається далі LM-a, який витлумачено як ціль або мету, і передбачається, що TR вступає в контакт із ціллю. Коли TR оминає ціль, він рухається ВИЩЕ і ЗА LM-a. У такий спосіб у сцені концептуалізовано РУХ ЗАДАЛЕКО, або 
вона містить надлишок. Про відмінність цього значення від протосцени свідчить подальше розширення семантики, яке не можна пояснити за допомогою контексту.

В українській мові є два варіанти вербалізації ситуації в такій просторовій сцені (28): 1. значення 'надлишок’ репрезентує дієслівний префікс пере-, розташування у просторі, співвідносному з LM-ом - прийменник через (29); 2. прийменник над профілює ключову позицію TR-a у такій просторовій конфігураціії - вище LM-a (30), а на надлишковість вказують властивості концепту ЦІЛЬ, у яку прототипно має влучити стріла, але не влучає.

(29) Стрріла перелетіла через изіль і впала десь у лісі.

(30) Стріла полетіла над иүіллю і впала десь у лісі.

Але ані через, ані над не схематизують просторові відношення 'Надi-3a', як over. Такі відношення може репрезентувати цілий контекст, часто з поєднанням конструкцій із прийменниками через та за, як у (31). Прийменник через концептуалізує просторову конфігурацію, у якій TR розташовано у просторі, співвідносному з LM-ом, у полі взаємодії, i вже від контексту залежить конкретизація точки розташування TR-a. У просторовій сцені з через LM концептуалізується як перешкода, і вже від характеристик LM-a i TR-a залежить, яким шляхом TR може подолати цю перешкоду. Наприклад, контекст (32) репрезентує сцену, де TR оминає LM згори, а (33) - ситуацію, в якій TR проходить між елементами LM-a.

(31) Часом стріли перелітали через ціль і падали аж за межею поля.

(32) 3 відстані ста кроків вони перелітали ще й через двадиятиметрове дерево, а з тридияти пробивали дошку.

(33) Стріла пролетіла через листя, не зачепивиись за жодну гілку.

Схему надлишку для через пов’язано з концептуалізацією LM-a як частини КОНТЕЙНЕРА (34). У такій сцені LM може бути представлено словами край, верх, віния, які позначають верхню межу стінки контейнера. Схема надлишку властива і прийменнику preko (35). Оскільки держава також концептуалізується як КОНТЕЙНЕР, їі кордони ство- 
рюють певні перешкоди для пересування людей. Якщо рух поза межі держави з якихось причин заборонений, то шлях, який виходить за кордон, сприймається як РУХ ЗАДАЛЕКО, (36).

(34) Бармен ... наповняючи лямпки смолисто-тягучою, мов розтоплений бурштин, рідиною, переливає через верх...

(35) ...sve što ne dobiješ na početku čeka te na kraju, sve što zgrabiš preko crte moraćeš dvostruko da platiš...

(36) Sve devojke koje je preveo preko granice bile su u pratnji muževa.

Схема покриття

Прототипною $є$ ситуація, в якій TR менший за розміром, ніж LM. Проте в реальному світі бувають випадки, коли об’єкт у фокусі, тобто TR, виявляється більшим або сприймається як більший, ніж локус, LM. Побудова значення 'Покриття' (The Covering Sense) у нормальних умовах містить дві зміни у звичній репрезентації протосцени: поперше, TR сприймається як більший, ніж LM, і по-друге, точка зору зміщується з позиції „поза сценою“ (“off-stage”) у позицію „вище, ніж LM“ (Tyler, Evans 2003: 83):

(37) The tablecloth is over the table.

(38) The fibreglass protector was over the swimming pool.

В українській і сербській мовах схема покриття властива прийменникам над і на. Обов'язковою характеристикою протосцени прийменника нає контакт між TR-ом та LM-oм, LM має горизонтальну поверхню, зверху якої й розміщено TR (39), (40), а прийменник над вживають, коли контакт відсутній (41), (42). Розмір TR-а не вносить змін у схематизацію просторової сцени, як це характерно для прийменників on і over.

(39) Скатертина лежить на столі.

(40) Na stolu je ležala stolnjaka.

(41) Він помітив сухий столик, захищений від дощу парасолькою, яка вивищувалася над ним, як гриб над мурашкою.

(42) Poput kipova od prašine, bezbrojni stubovi neiskopane zemlje su se uzdizali da podrže zemljano nebo, koje je visilo nisko nad senovitim naseljem. 


\section{Значення 'Вивчення'}

Будь-яку просторову сцену можна розглядати з різних точок зору. Прототипна точка зору, пов' язана з протосценою, в якій спостерігач перебуває „поза сценою”. Конструювання смислу over, який проілюстровано в (43), $\epsilon$ результатом зміщення точки зору. Тут представлено точку зору TR-a, i більше того, погляд TR-a спрямовано на LM (Tyler, Evans 2003: 93).

(43) Phyllis is standing over the entrance to the underground chamber.

Тут протосцена over не зазнає значних змін у просторовій сцені, але відбуваються зміни у патерні „рівень уваги“ (level of attention). TR розташовано вище, але у безпосередній близькості до LM-a, тобто TR перебуває у такій позиції, у якій може спостерігати за входом і здатен помічати деталі. „Якщо об’єкт перебуває недостатньо близько до спостерігача, зазвичай він $є$ недостатньо чітким для сприйняття спостерігача, оскільки той не може роздивитися деталі““ (Tyler and Evans 2003: 93).

Прийменник над може вказувати на різницю в розмірі TR-a й LM-a. Випадки (44), (45), (46) засвідчують, що лише частину TR-a може бути розташовано безпосередньо НАД LM-ом. Як для over, так і для над властива поява відмінного значення 'Вивчення', зумовлена зручністю такої позиції TR-a у просторовій сцені для уважного спостереження за LM-oм.

(44) Ще він побачив навколо себе голови - иіле товариство згромадилося над шахівницею, збуджено обговорюючи становище...

(45) Карл-Йозеф обережно відклав убік свого меча і периим схилився над заюшеним Пепою.

(46) Kada je stigao, iznenadilo ga je što vidi dve devojke uzbuđeno nagnute nad instrumente.

Таким чином, я розглянула основні просторові сцени, які репрезентує прийменник over англійської мови. Зіставлення 3 вербалізацією подібних просторових відношень українською і сербською мовами дало змогу з'ясувати, що різним значеннями over відповідають образні схеми, властиві різним прийменникам української мови: не тільки над і через, а й почасти за і на. Просторова семантика прийменників 
сербської мови preko i nad доволі подібна до семантики українських прийменників. Доходимо висновку, що носії української та сербської мов концептуалізують представлений набір схем просторових відношень не як ланцюжок пов'язаних між собою варіацій, похідних від однієї протосцени, кожній із яких властива одна або дві зміни у сцені, що зумовлюють появу іншого значення, але як різні схеми, які представляють різні категорії просторових відношень і не пов’язані між собою дериваційно.

\section{Література}

Brenda M., 2014, The Cognitive Perspective on the Polysemy of the English Spatial Preposition over, Cambridge: Cambridge Scholars Publishing.

Brugman C., 1988, The Story of Over: Polysemy, Semantics and the Structure of the Lexicon, New York: Garland.

Evans V., Tyler A., 2004, Rethinking English „Prepositions of Movement”: The Case of To and Through, in: H. Cuyckens at all. (ed.), Adpositions of Movement (Belgian Journal of Linguistics, 18), Amsterdam: John Benjamins, pp. 247-270.

Herskovits A., 1986, Language and Spatial Cognition: Interdisciplinary Study, Cambridge: Cambridge University Press.

JANDA L., 1986, A semantic analysis of the Russian verbal prefixes za-, pere-, do-, and ot-, in: Slavistische Beiträge, B. 192, München: Otto Sagner.

KuIKovac D., 2006, Semantika predloga. Studija iz kognitivne lingvistike, Beograd: Filološki fakultet.

Lakoff G., 1990, Women, Fire, and Dangerous Things, Chicago: Chicago University Press.

Langacker R., 2000, Grammar and Conceptualization, Berlin-New York: Walter de Gruyter.

Levinson S., 2003, Spatial language, in: Nadel L. (ed.), Encyclopedia of cognitive science, London: Nature Publishing Group, pp. 131-137.

PIPER P., 2001, Jezik i prostor, Beograd: Biblioteka XX vek.

Przybylska R., 2002, Polisemia przyimków polskich w świetle semantyki kognitywnej, Kraków: Universitas.

Przybylska R., 2006, Schematy wyobrażeniowe a semantyka polskich prefiksów czasownikowych do-, od-, prze-, roz-, u-, Kraków: Universitas.

Rasulić K., 2004, Jezik i prostorno iskustvo, Beograd: Filološki fakultet. 
ŠArić Lu., 2008, Spatial Concepts in Slavic: A Cognitive Linguistics Study of Prepositions and Cases, Wiesbaden: Harrassovitz Verlag.

Talmy L., 2000, Toward a Cognitive Semantics: Concept Structuring Systems, Vol. 1, Cambridge, MA: MIT Press.

Tyler A., Evans V., 2003, The Semantics of English Prepositions: Spatial scenes, Embodied Meaning and Cognition, Cambridge: Cambridge University Press.

Вихованець I., 1980, Прийменникова система украӥнської мови, Київ: Наукова думка.

Вихованець I., 2002, Лексико-граматичне опрацювання прийменників української мови, Українська мова, №4, с. 90-96.

ВиховАнЕЦь I. (ред.), 2009, Функиіонально-комунікативна і текстова парадигма украӥнських прийменників та їхніх еквівалентів, Донецьк: Вебер.

ВСеволодовА М., 2004, „Предлоги в синхронии и диахронии: морфология и синтаксис". Первые результаты межнационального проекта, в: Функиіональнокомунікативні аспекти граматики і тексту, Донецьк: ДонНУ, с. 173-180.

ЗАГнгтко А., 2002, Первинна і вторинна прийменникова категорійна семантика: статус, варіантність, у: Культура народов Причерноморья, № 32, С. 190-194.

ЗАгнгтко А., 2004, Українські прийменники: інвентар і структура, в: Лінгвістичні студї. Вип. 12, Донецьк: ДонНУ, с. 41-47.

ЗАгнгтко А., 2008, Ступені і рівні прийменниковості, в: J. Anderš, H. Flidrová, U. Cholod (red.), Ucrainica IV. Současná ukrajinistika: Problémy jazyka, literatury a kultury, 1. čast, Olomouc: Univerzita Palackého v Olomouci, c. 17-22.

ЗАгнітко А., 2014, Теорія граматики і тексту, Донецьк: Ноулідж.

Ивић М., 1958, Систем предлошких конструкција у српскохрватском језику, Јужнословенски филолог ХХІІ, Књ. 1-4, с. 141-166.

Ивић М., 2010. Квалификативна улога генитивне именичке форме с предлогом од, у: Јужнословенски филолог LXVI, с. 269-271.

Поповић Љ., 2008, Језичка слика стварности: когнитивни аспект контрастивне анализе, Београд: Филолошки факултет.

PCJ, 2011, Речник српскога језика, Нови Сад: Матица српска.

СУМ, 1974, Словник української мови, В 11-ти томах, Т. 2., К.: Наукова думка.

СУМ, 1980, Словник украӥнської мови, В 11-ти томах, Т. 5., К.: Наукова думка. 


\section{The Schematization of Spatial Relations in English, Serbian and Ukrainian:} the Specifics of the Preposition over

\section{(summary)}

The study focuses on the schematization of natural categories of the meaning in the preposition over, and contrasting it with the schematization of relevant spatial relations in Serbian and Ukrainian. Contrasting similar verbalizations of spatial relations in Ukrainian and Serbian has enabled us to conclude that distinct senses of over correlate with image-schemas characteristic for various Ukrainian prepositions - mainly над and через, but also partially за and на, and Serbian prepositions preko and $n a d$. We deduce that in Ukrainian and Serbian the presented set of scenes are not conceptualized as a chain of connected variations derived from the same proto-scene and possessing one or two changes in the scene that provoke a distinct sense, but rather as different scenes that represent various categories of spatial relations, and they are not connected via derivation. 